\title{
Challenges and Prospects of the Southern Kuril Islands' Status
}

\author{
Viatcheslav Gavrilov
}

\author{
Professor of Law, Head Chair of International Public and Private Law,Far Eastern Federal University \\ (Vladivostok, Russia).S.J.D., Doctor of Law; gavrilovfirst@gmail.com; gavrilov.vv@dvfu.ru
}

\section{Doi:10.5901/mjss.2016.v7n1p301}

\begin{abstract}
The paper provides a retrospective review on and analyses the current situation of the Southern Kuril Islands international legal status. It examines positions of Russia and Japan regarding this issue and ends with some proposals in order to reduce RussoJapanese bilateral tensions caused by territorial dispute over these Islands. The main deduction of the paper provides that this problem cannot be finally solved nowadays by Russia and Japan solely based on current international legal agreements, which can be interpreted differently.
\end{abstract}

Keywords: international law; international agreements, territorial dispute, sovereignty, Russia, Japan, Southern Kuril Islands.

\section{Introduction}

The disagreements between Russia and Japan concerning the territorial status of the Kuril Islands have arisen after the Second World War and nowadays seriously influence the whole spectrum of Russo-Japanese relations and leave their future in serious doubt. In order to prove the legitimacy of their positions each of the parties refers to a significant number of historical, political, economic, cultural and social and demographic facts and observations, which, however, while without doubt being significant, cannot become a basis for the consensus building process between Russia and Japan on the subject. It is obvious that such a consensus can be achieved solely on the ground of norms and principles of contemporary international law, but taking into account the retrospective view on the development of Russo-Japanese contractual relationships and relations of other countries affecting the Kuril Islands dispute.

In this light, the article provides a retrospective review on and analyses the current situation of the Southern Kuril Islands international legal status. It examines positions of Russia and Japan regarding this issue in agreements of Shimoda (1855), Portsmouth (1905) and Beijing (1925) as well as contains a review of other important international documents adopted during and after World War II, including famous San Francisco Treaty of 1951 and Soviet-Japanese Joint Declaration of 1956. The article ends with some proposals in order to reduce Russo-Japanese bilateral tensions caused by territorial dispute over these Islands. The main deduction of the paper provides that this problem can not be finally solved nowadays by Russia and Japan solely based on current international legal agreements, which can be interpreted differently.

\section{Historical Premises of the Dispute}

Before the year of 1855 there had been no official boundary between Russia and Japan. The Treaty of Commerce, Navigation and Delimitation of February 7, 1855 (also known as the Treaty of Shimoda) became the first treaty to delimitate the territories of the two countries. According to this document, the Russo-Japanese border in the Kuril Islands was drawn between the islands of Iturup and Urup (12). Everything north of this line was granted to Russia and everything south was Japanese (namely the disputed islands: Iturup, Kunashir, Shikotan and a group of islets together known as Habomais). The main purpose of the treaty was to establish "eternal peace and sincere friendship among Russia and Japan". The Treaty opened three Japanese harbors to Russian vessels: the ports of Shimoda, Hakodate and Nagasaki. Moreover, Russia acquired the right to open its consulates in the ports mentioned and was accorded the mostfavoured-nation treatment in the field of commerce.

According to the Treaty of Shimoda Sakhalin was not supposed to be partitioned between the two parties and was declared to be a de-militarized zone. However, in after years the Japanese tried repeatedly to settle down on it and on the Northern Kuril Islands, which had been retroceded to Russia in compliance with the Treaty of Shimoda. In order to halt down the contradictions that were ready to arise, a new treaty was signed between the two countries in Saint-Petersburg 
in 1875. In the Treaty of Saint-Petersburg, Russia gave up the sovereignty over its part of the Kuril Islands in exchange for the sole ownership of Sakhalin (11).

As a result of Russo-Japanese war of 1904-1905, Russia ceded the southern part of Sakhalin to Japan, which was occupied by Japanese forces at that time. This cession found its fixation in the Portsmouth Peace Treaty signed between Russia and Japan on September 5, 1905 (7). At that Japan gave up its initial claims to limit the naval forces of Russia on the Far East, to give out the interned Russian vessels and to pay the contribution in order to return the northern part of Sakhalin to Russia. Moreover, Japan guaranteed free navigation in the Strait of La Perouse and gave a promise not to construct any fortifications on the Southern Sakhalin. It is interesting to note that in Japan the execution of the Treaty of Portsmouth was received as a defeat and caused mass disorders in Tokyo.

Thus, to the moment the Russian Empire collapsed in 1917 both Southern Sakhalin and Kuril Islands de jure were no more owned by Russia. On establishing diplomatic relations with Japan in 1925, the Soviet Government avowed this fact and recognized the Portsmouth Peace Treaty, but, at the same time, declared that the "USSR did not bear political responsibility for it". However, the revision of the Treaty of Portsmouth was not stipulated by the Soviet-Japanese Basic Convention of 1925 (the Treaty of Beijing), even despite the fact that all other treaties, agreements and conventions, which had been concluded between Russia and Japan prior to November 7, 1917, were to be revised pursuant to the Treaty of Beijing (3).

Territorial dispute between the USSR and Japan arose again at the end of the Second World War. At that time the allies of the Soviet Union within the anti-Hitler coalition tried to involve the USSR in the war with Japan promising to return Southern Sakhalin and Kuril Islands to the Soviet Union after the war would be over. Such an obligation was fixed in Yalta (Crimea) Accords of three Great Powers on issues concerning the Far East, which was signed by Stalin, Roosevelt and Churchill on February 11, 1945 in Yalta (1; p. 81-82).

The Cairo declaration (signed by the USA, Great Britain and China on November 27, 1943) went before the Yalta Agreement. It stipulates that though the allies "covet no gain for themselves and have no thought of territorial expansion" the purpose of the Allied Powers is "that Japan shall be stripped of all the islands in the Pacific which she has seized or occupied since the beginning of the first World War... and Japan also shall be expelled from all other territories which she has taken by violence and greed" (1; p. 104-105).

The Soviet Union affirmed that thanks to the Yalta Agreement a legal confirmation was received concerning the transfer of the Kuril Islands, including the islands of Iturup, Kunashir, Shikotan and Habomais, to the USSR. Japan does not agree with it and does not consider the Crimea Agreement to be a basis for the final territorial dispute settlement, as Japan has not been a party to this agreement so she is bound by its provisions neither juridically nor politically. However, she accepted the Potsdam Declaration under the names of the USA, Great Britain and China of July 26, 1945, to which the Soviet Union acceded on August 8, 1945 (1; p. 105-106). In this document it is fixed that the terms of the Cairo declaration shall be carried out and Japanese sovereignty shall be limited to the islands of Honshu, Hokkaido, Kyushu, Shikoku and such minor islands as the allies determine.

Pursuant to the Yalta Agreement, the Soviet Union proclaimed war against Japan on August 8, 1945 (8). The statement of the USSR Government of April 5, 1945 concerning the denunciation of the Soviet-Japanese Neutrality Pact of April 13, 1941, which had entered into force on April 25, 1941, preceded this war declaration. This statement was made in accordance with Article 3 of the Pact, in which it is stipulated that the Pact "remains valid for 5 years and that in case neither of the Contracting Parties denounces the Pact one year before the expiration of the term, it will be considered automatically prolonged for the next five years" (4). Nevertheless, as it was declared repeatedly by the representatives of Japan, the Pact was to remain valid up to April 25, 1946, in other words even after the USSR statement had been made.

In the course of the Soviet-Japanese war in August - the beginning of September of 1945, the Soviet Union occupied Southern Sakhalin and the islands of Iturup, Kunashir, Shikotan and Habomais, which were annexed into the RSFSR on February 2, 1946 by the Decree of the Presidium of the Supreme Soviet of the USSR.

\section{San Francisco Treaty of 1951 and Soviet-Japanese Joint Declaration of 1956}

In several years a question arose concerning the conclusion of a peace treaty with Japan, which would draw a final line under the war and settle all territorial disputes. Such a treaty was signed on September 8, 1951 in San Francisco. Its Article 2 (c) stipulated that Japan renounced all rights, title and claim to the Kurile Islands and Southern part of Sakhalin. At that the Treaty did not note to what country the mentioned territories were to be transferred.

The Soviet Union did not sign that Treaty. Nevertheless, it is believed that under the San Francisco Treaty the mentioned territories were to be transferred solely to the Soviet Union because Japanese renunciation of the territories, 
over which she had obtained sovereignty pursuant to Portsmouth and Saint-Petersburg treaties, meant the restoration of rights to these territories for their original owner, e.g. for Russia.

Two above-mentioned circumstances are not able to influence the fact that Japan renounced the territories fixed in Article 2 (c) of the Treaty of 1951 and at the first sight deprive her of all legal authorities for its territorial claims to south Kuril Islands. But Japan does not think so and her official representatives repeatedly declared that the islands of Iturup, Kunashir, Shikotan and Habomais just were not a part of Kuril Islands and so the renunciation provided in the San Francisco Treaty did not apply to them. However, there is evidence that Japanese parliament ratified the San Francisco peace treaty of 1951 as it considered the treaty to cover the Southern Kuril Islands (6).

In any way this statement appears to be legally groundless, especially because of the fact that earlier Japan recognized the validation of the Potsdam Declaration, to which the Soviet Union was a party and which limited the Japanese sovereignty to the islands of Honshu, Hokkaido, Kyushu, Shikoku and such minor islands as the allies would determine. Moreover, Article 8 of the 1951 San Francisco Peace Treaty directly states, "Japan will recognize the full force of all treaties now and hereafter concluded by the Allied Powers for terminating the state of war initiated on 1 September 1939, as well as any other arrangements by the Allied Powers for or in connection with the restoration of peace". Within the context of this article a question must be posed concerning the fact that Japan de jure recognized the provisions of the Crimea Declaration of 1945, which stipulated the hanging over of Kurils and Southern Sakhalin to the USSR after the war.

In any case, by virtue of the fact that this question had not been juridically clarified in a proper way at that time, and because the Soviet Union had not signed the San Francisco Peace Treaty of 1951, certain negotiations concerning the conclusion of a peace treaty were held between the USSR and Japan. But they failed to reach accord because of the divergence of views on territorial issues. Nevertheless, a Soviet-Japanese Joint Declaration was signed on October 19, 1956 (2). This declaration put an end to the state of war and restored diplomatic and consular relations between the two countries. The Declaration was ratified by the Japanese parliament on December 5, 1956 and by the Presidium of the Supreme Soviet of the USSR on December 12, 1956. The exchange of ratifications took place in Tokyo on December 12, 1956. That day the Declaration of 1956 entered into force and obtained the status of an international treaty.

Article 9 of this international legal document stated, "the USSR, desiring to meet the wishes of Japan and taking into consideration the interests of Japan, agreed to hand over to Japan the Habomai Islands and the island of Shikotan. However, the actual handing over of these islands to Japan shall take place after the conclusion of a peace treaty between the Soviet Union and Japan". Such hanging over did not take place in 1960 because of the aggravation of the Soviet-Japanese relations caused by the prolongation by Japan of the USA-Japanese Mutual Security Treaty, which gave legal authority for the American troops to stay within the Japanese territory. Moreover, during the next several decades the USSR denied the presence of any territorial dispute within Soviet-Japanese relations.

\section{Russian-Japanese Stage of the Southern Kuril Dispute}

Russia, as a successor of the USSR, officially readmitted its territorial dispute with Japan concerning the Kurils in Tokyo Declaration on Japan-Russia relations signed by the Japanese Prime Minister M. Hosokawa and Russian President B.N. Yeltsin on October 13, 1993. In this document it was stated that as a result of the discussion on territorial belonging of the islands of Iturup, Kunashir, Shikotan and Habomais the parties agreed that "negotiations towards an early conclusion of a peace treaty through the solution of this issue on the basis of historical and legal facts and based on the documents produced with the two countries' agreement as well as on the principles of law and justice should continue, and that the relations between the two countries should thus be fully normalized" (10). Some years later an Irkutsk Statement concerning further talks on a peace treaty was signed on March 25, 2001 as a result of a working meeting between the President V.V. Putin and Prime Minister Y. Mori in Irkutsk. The Declaration of 1956 was mentioned for the first time in many years as a "basic legal document that established the starting point in the negotiation process for the conclusion of a peace treaty subsequent to the restoration of diplomatic relations between both countries" (5). Later the Russian Government more than once expressed its readiness to conduct territorial negotiations with Japan on the basis of the Declaration of 1956.

Unfortunately, such obvious readiness of Russia to finally settle the territorial dispute with Japan on south Kuril Islands has not found yet an adequate answer from Japan. Apparently, Japan considered Russia's acknowledgement of the territorial dispute existence and its suggestion to use the provisions of the 1956 Declaration as a starting point for negotiations to be the sign of weakness and readiness to make unilateral concessions, but not a sincere intention to found a basis for a consensus building process. Otherwise, it is difficult to understand the statements made by official representatives of the Japanese Government about an absolute necessity of four Southern Kuril Islands' return to Japan 
and about their denial to conclude a peace treaty with Russia on other conditions. The acceptance by the Japanese Upper Chamber of amendments to the law "About special measures promoting solution of the problem of Northern Territories", which had taken place on July 3, 2009, no doubt brought no progress to the situation. These amendments contained a provision on the Japanese indisputable ownership of the four Southern Kuril Islands.

It is obvious that, by virtue of the fact that Russia and Japan agreed to further negotiations concerning Southern Kuril Islands at the end of XX and beginning of XXI century, the continuation of talks should and is to take place, but will be useless until the Japanese position is changed.

\section{Implications and Suggestions}

All the above-mentioned allow us to conclude that:

1. The territorial dispute between Russia and Japan concerning the sovereignty over the islands of Iturup, Kunashir, Shikotan and Habomais still exists. This fact should be recognized both from juridical and political points of view.

2. This territorial dispute cannot be finally solved nowadays by Russia and Japan solely on the basis of current international legal agreements because of the lacunas' presence in them, so the agreements can be interpreted differently by the parties. The above agreements in some sense give the parties a reasonable basis to dispute present-day and future territorial status of the islands. At this, we consider the Japanese renunciation of all claims to Kuril Islands and limitation of its sovereignty to the islands of Honshu, Hokkaido, Kyushu, Shikoku and some islets, stated in the 1945 Potsdam Declaration and 1951 San Francisco Peace Treaty, to be the most significant argument from our side. As well as we consider the Soviet Union's nonparticipation in San Francisco Treaty and the lack of exact instructions in it on who should possess these islands to be the strongest argument from the Japanese side.

3. In compliance with the principles of current international law, which provide for the necessity of any dispute amicable settlement, there are two possible ways out of the situation:

3.1. To submit the dispute to a competent and authoritative international body, the decision of which shall be final and legally binding for both parties. For example, the International Court of Justice could serve as such a body, as pursuant to Article 36 of the Statute of the International Court of Justice (9), it is entitled to consider all legal disputes regarding, particularly, the interpretation of a treaty as well as any question of international law, in case the parties recognize its jurisdiction. But this variant seems to be unlikely as Russia and Japan are not ready to submit the dispute to the third party because the issue has a high level of political nature and because the two countries are not confident in their positions' legal sufficiency.

3.2. To further negotiations between the countries in order to reach a mutually acceptable compromise and to fix it in a form of international legal agreement legally binding for the parties. At this the Declaration of 1956 can serve as a basis for the beginning of negotiations as the only document on the south Kurils' issue, which was ratified after the termination of the World War II both by Japan and Russia and which imposed legal obligations on them. But it should be kept in mind that in Paragraph 9 of the Declaration of 1956 the question is about the hanging over to Japan the Habomai Islands and the island of Shikotan but not about the restoration of her rights to these islands. In other words one explicitly connect the readiness of Russia, reflected in the 1956 Declaration, to hang over to Japan the islands of Shikotan and Habomais with the readiness of the Japanese party to meet the wishes of Russia to settle the territorial dispute and to conclude a peace treaty.

4. Taking into account the sensitivity of the south Kurils' issue for Russia and Japan, the intermediate and final formula of its solution should not necessarily declare the sovereignty of a concrete country over a concrete territory. The mutual agreement over mechanisms of exploitation (possession) of disputable territories (or their part) and sea spaces attached to them seems to be much more effective for these territories' rapid economic and infrastructural development, of course, on condition that the freedom of the high sea will be guaranteed and adequate level of life for the islanders will be maintained. Such an approach would allow to significantly relax tension in Russo-Japanese relations, to dispel suspicions concerning each other and to create opportunities for close and fruitful co-operation in order to promote bilateral relations and to solve regional and universal problems just prior to putting an end to the dispute of the Southern Kurils' territorial status (in case such a decision takes place).

5. Conclusion of a treaty of friendship, good-neighborliness and cooperation between Russia and Japan can become one of the effective steps on this way. Such a treaty will be able to influence the practical problems 
solving concerning Southern Kurils, to create legal base for the development of Russo-Japanese cooperation in all directions, including non-proliferation of nuclear weapons, turning the Korean peninsula into a nuclearweapon-free zone, which is important for Japan as a non-nuclear power, fight against terrorism and piracy, environment protection (forests of the Russian Far East are "the lungs of Japan"), armament race reduction all over the world, cooperation within UN frameworks and within the frames of other international universal and regional organizations. In the treaty it can be mentioned that its conclusion doesn't touch positions of the parties concerning territorial dispute.

Such an approach enables Russia and Japan to give an impulse to bilateral cooperation development, to bring substantial contribution to a new security system creation in North-East Asia and to postpone territorial dispute solving till both parties are ready to make mutual concessions in order to obtain mutually-beneficial result.

\section{References}

Collection of Existing Treaties, Agreements and Conventions Concluded Between the USSR and Foreign Countries (1955). Issue XI. Moscow: International Relations. (In Russian).

Collection of International Treaties of the USSR (1984). Issue XXXVIII. Moscow: International Relations. (In Russian).

Convention Embodying Basic Rules of the Relations Between Japan and the Union of Soviet Socialist Republics, and Declaration (1925), Article 2. Joint Compendium of Documents on the History of Territorial Issue between Japan and Russia. [Online] Available: http://www.mofa.go.jp/region/europe/russia/territory/edition92/period3.html (September 16, 2015).

History of the Pacific War. Vol. III. The First Period of the War (1958). Moscow: Foreign Literature. (In Russian).

Irkutsk Statement by the Prime Minister of Japan and the President of the Russian Federation on the Continuation of Future Negotiations on the Issue of a Peace Treaty. [Online] Available: http://www.mofa.go.jp/region/europe/russia/pmv0103/state.html (September $21,2015)$.

Khlestov, O.N. (2010). South-Kuril Problem in Russian-Japanese Relations. International Public and Private Law, 4, 2-8.

Portsmouth Peace Treaty (1905), Article 9. Joint Compendium of Documents on the History of Territorial Issue between Japan and Russia. [Online] Available: http://www.mofa.go.jp/region/europe/russia/territory/edition92/period2.html (September 16, 2015).

Statement by the Soviet Government to the Government of Japan, 8 August 1945. Joint Compendium of Documents on the History of Territorial Issue between Japan and Russia (1992). Moscow: Ministry of Foreign Affairs of Russia and Ministry of Foreign Affairs of Japan. (In Russian).

Statute of the International Court of Justice. [Online] Available: http://www.icj-cij.org/documents/index.php?p1=4\&p2=2\&p3=0 (September 21, 2015).

Tokyo Declaration on Japan-Russia Relations. New Edition of the Joint Compendium of Documents on the History of Territorial Issue between Japan and Russia. [Online] Available: http://www.mofa.go.jp/region/europe/russia/territory/edition01/tokyo.html (September 21, 2015).

Treaty for Exchange of Sakhalin for the Kurile Islands (1875), Article 2. Joint Compendium of Documents on the History of Territorial Issue between Japan and Russia. [Online] Available: http://www.mofa.go.jp/region/europe/russia/territory/edition92/period2.html (September 16, 2015).

Treaty of Commerce, Navigation and Delimitation between Japan and Russia (1855), Article 2. Joint Compendium of Documents on the History of Territorial Issue between Japan and Russia. [Online] Available: http://www.mofa.go.jp/region/europe/russia/territoryl edition92/period1.html (September 16, 2015). 